\title{
Hyponatremia in Cancer Patients Hospitalized in a Palliative Care Department: A Cross-Sectional Analysis
}

\section{Hiponatremia em Doentes com Cancro Internados num Serviço de Cuidados Paliativos: Uma Análise Transversal}

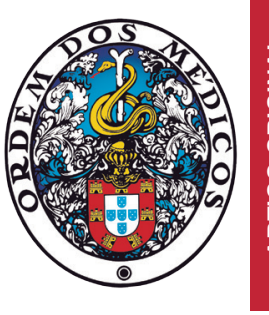

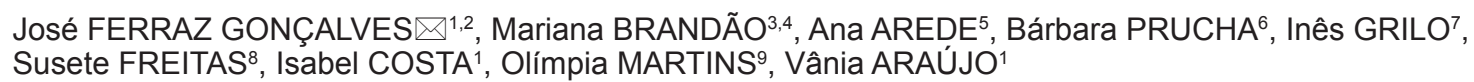

Acta Med Port 2022 Feb;35(2):105-110 - https://doi.org/10.20344/amp.15810

\section{ABSTRACT}

Introduction: Hyponatremia is frequent in cancer patients, as many studies carried out in these patients have shown. However, there are only a few studies carried out at the end of life and in palliative care. The aim of this study was to determine the prevalence of hyponatremia in cancer patients in the palliative care department of an oncology center and its association with survival.

Material and Methods: The study included the first 300 patients hospitalized in the palliative care department in 2017. Survival was measured from the day of hospitalization until death.

Results: Serum sodium was measured in 170 (59\%) patients. The median serum concentration was $135 \mathrm{mmol} / \mathrm{L}$ (109 to 145). Among $91(54 \%)$ patients, serum sodium was within the normal range, $59(35 \%)$ had mild hyponatremia, $13(8 \%)$ had moderate and seven (4\%) had profound hyponatremia. The median survival was 13 days (1 to 1020). Serum sodium was not significantly associated with survival $(p=0.463)$. Regarding other variables, the Eastern Cooperative Oncology Group performance status was significantly associated with survival, while gender, age, primary cancer and number of metastatic sites were not.

Conclusion: Hyponatremia is common in cancer patients receiving palliative care but did not seem to influence survival.

Keywords: Hyponatremia; Neoplasms/complications; Palliative Care

\section{RESUMO}

Introdução: A hiponatremia é frequente em doentes com cancro, como muito estudos realizados nesses doentes mostraram. Contudo, há poucos estudos no fim da vida e em cuidados paliativos. O objectivo deste trabalho foi estudar a prevalência da hiponatremia em doentes oncológicos num serviço de cuidados paliativos de um centro oncológico e a sua associação com a sobrevivência.

Material e Métodos: O estudo incluiu os primeiros 300 doentes internados no serviço de cuidados paliativos em 2017. A sobrevivência foi medida do dia da hospitalização até à morte.

Resultados: O sódio plasmático foi medido em 170 (59\%) doentes. A mediana da concentração de sódio plasmático foi $135 \mathrm{mmol} / \mathrm{L}$ (109 a 145). Em 91 (54\%) doentes, o sódio plasmático estava dentro dos valores de referência, 59 (35\%) tinham hiponatremia ligeira, em $13(8 \%)$ era moderada e sete (4\%) tinham hiponatremia profunda. A mediana da sobrevivência foi de 13 dias (1 a 1020). O sódio plasmático não apresentou uma associação estatisticamente significativamente associado com a sobrevivência $(p=0,463)$. Quanto a outras variáveis, o estado de performance do Eastern Cooperative Oncology Group associou-se significativamente à sobrevivência, 0 que não se verificou com o género, a idade, o tumor primário e o número de locais de metástases.

Conclusão: A hiponatremia é comum nos doentes oncológicos em cuidados paliativos, mas não parece influenciar a sobrevivência.

Palavras-chave: Cuidados Paliativos; Hiponatremia; Neoplasias/complicações

\section{INTRODUCTION}

Hyponatremia is a water balance disorder which develops when the amount of water is excessive in relation to the existing sodium stores in the body. It is the most frequent hydroelectrolytic imbalance found in clinical practice. ${ }^{1}$ Hyponatremia is usually defined as a serum sodium concentration below $135 \mathrm{mEq} / \mathrm{L}$. The clinical symptoms may be very varied, from none to life-threatening, depending on the level of serum sodium concentration, the speed of development and the previous general clinical condition of the patient.

The most common causes of hyponatremia are the syndrome of inappropriate antidiuretic hormone secretion (SIADH), diuretic use, polydipsia, adrenal insufficiency, hypovolemia, heart failure and liver cirrhosis. ${ }^{2}$ There are other possible causes, such as iatrogenesis from drugs ${ }^{3-5}$ and hypotonic intravenous fluids, ${ }^{6}$ and pseudo-hyponatremia due, for example, to hyperlipidemia. ${ }^{7}$

In cancer patients, hyponatremia is often caused by SI$\mathrm{ADH}$ triggered by the ectopic antidiuretic hormone $(\mathrm{ADH})$ secretion by tumor cells. ${ }^{8}$ Drugs used in cancer treatment, such as vinca alkaloids, vincristine and vinblastine, alkylating agents, such as cyclophosphamide, and targeted

1. Serviço de Cuidados Paliativos. Instituto Português de Oncologia do Porto. Porto. Portugal.

2. Departamento Medicina da Comunidade, Informação e Decisão em Saúde. Faculdade de Medicina. Universidade do Porto. Porto. Portugal.

3. Medical Oncology Department. Instituto Português de Oncologia do Porto. Porto. Portugal.

4. Academic Trials Promoting Team. Institut Jules Bordet. Brussels. Belgium.

5. Serviço de Oncologia. Centro Hospitalar Universitário do Algarve. Faro. Portugal.

6. Unidade de Saúde Familiar Navegantes. Agrupamento de Centros de Saúde Póvoa de Varzim/ Vila do Conde. Póvoa de Varzim. Portugal.

7. Serviço de Oncologia. Centro Hospitalar de Trás-os-Montes e Alto Douro. Vila Real. Portugal.

8. Unidade de Cuidados Paliativos. Hospital Dr. João d'Almada. Funchal. Madeira. Portugal.

9. Unidade de Cuidados Paliativos. Centro Hospitalar Tâmega e Sousa. Guilhufe. Portugal.

$\triangle$ Autor correspondente: José Ferraz Gonçalves. ferrazg@netcabo.pt

Recebido: 26 de janeiro de 2021 - Aceite: 14 de abril de 2021 - First published: 24 de maio de 2021 - Online issue published: 01 de fevereiro de 2022 Copyright $\odot$ Ordem dos Médicos 2022 
therapies (monoclonal antibodies, tyrosine kinase inhibitors, immunomodulators and mammalian target of rapamycin inhibitors) may also induce SIADH. Moreover, platinum compounds stimulate ADH secretion, but can also cause hyponatremia by interfering with sodium reabsorption by directly damaging renal tubules and causing renal salt wasting syndrome or acquired nephrogenic diabetes insipidus. ${ }^{3}$ Opioids, antidepressants, tricyclics and selective serotonin reuptake inhibitors stimulate $\mathrm{ADH}$ secretion and nonsteroidal anti-inflammatory drugs potentiate its effects on the renal tubules. ${ }^{4,8}$ Another cause of hyponatremia is cerebral salt wasting, which may result from brain metastases, head trauma, meningitis or central nervous system (CNS) surgery. ${ }^{8}$ In cancer patients, hyponatremia occurs most frequently in small cell lung cancer, but it may occur in many other cancer types, both solid and hematologic. Hyponatremia was identified as an independent negative prognostic factor for survival in cancer patients. ${ }^{9-11}$ The nonnormalization of hyponatremia with antineoplastic treatment has also been associated with a worse prognosis. ${ }^{8}$

As far as we know from the few studies carried out concerning hyponatremia in palliative care, only two of them looked at the association of hyponatremia with survival. ${ }^{9,12}$ As data on hyponatremia in palliative care are so scarce, we carried out a study in our palliative care department with the aim of evaluating its prevalence and prognostic value.

\section{MATERIAL AND METHODS}

This study was carried out in the palliative care department (PCD) of an oncology center. The first 300 patients that were hospitalized in the PCD in 2017 were included in the study. The sample size was calculated based on 1000 admissions per year (historical data), a 95\% confidence interval and assuming a $50 \%$ prevalence of hyponatremia (heterogeneous in previous studies). Only patients with a blood sample collected for other reasons within three days of, or during admission, were studied. For ethical reasons, no blood samples were specifically collected from any patient for this study.

Hyponatremia was classified according to the Guideline on Diagnosis and Treatment of Hyponatraemia1: 'mild' - serum sodium between 130 and $135 \mathrm{mEq} / \mathrm{L}$; 'moderate'- serum sodium between 125 and $129 \mathrm{mEq} / \mathrm{L}$; 'profound' - serum sodium < $125 \mathrm{mEq} / \mathrm{L}$.

This study was approved by the ethics committee of the hospital.

Descriptive methods were used for the statistical analysis and the chi-squared test was used to assess the

Table 1 - Demographic data and comparison of patients tested and not tested

\begin{tabular}{|c|c|c|c|c|c|c|c|}
\hline \multirow[b]{2}{*}{ Gender } & \multicolumn{2}{|c|}{ Total } & \multicolumn{2}{|c|}{ Patients tested } & \multicolumn{3}{|c|}{ Patients not tested } \\
\hline & $n$ & $\%$ & $\mathbf{n}$ & $\%$ & $n$ & $\%$ & $p$ \\
\hline Male & 167 & 58 & 102 & 60 & 65 & 56 & \multirow{2}{*}{0.280} \\
\hline Female & 120 & 42 & 68 & 40 & 52 & 44 & \\
\hline \multicolumn{8}{|l|}{ Age } \\
\hline$\leq 69$ years & 145 & 51 & 81 & 47 & 64 & 55 & \multirow{2}{*}{0.467} \\
\hline$>69$ years & 142 & 49 & 89 & 53 & 53 & 45 & \\
\hline \multicolumn{8}{|l|}{ Primary cancer } \\
\hline Esophageal/ gastric & 56 & 20 & 33 & 19 & 23 & 20 & \multirow{9}{*}{0.673} \\
\hline Colorectal & 43 & 15 & 28 & 17 & 15 & 13 & \\
\hline Lung & 32 & 11 & 18 & 11 & 14 & 12 & \\
\hline Head and neck & 30 & 11 & 17 & 10 & 13 & 11 & \\
\hline Breast & 29 & 10 & 17 & 10 & 12 & 10 & \\
\hline Prostate & 19 & 7 & 15 & 9 & 4 & 3 & \\
\hline Gynecological & 14 & 5 & 8 & 5 & 6 & 5 & \\
\hline Other & 64 & 21 & 34 & 20 & 30 & 26 & \\
\hline Total & 287 & 100 & 170 & 100 & 117 & 100 & \\
\hline \multicolumn{8}{|c|}{ Disease extension/ Number of metastatic sites } \\
\hline 1 & 77 & 27 & 40 & 24 & 37 & 32 & \multirow{4}{*}{0.451} \\
\hline 2 & 102 & 36 & 62 & 37 & 40 & 35 & \\
\hline 3 & 68 & 24 & 44 & 26 & 24 & 21 & \\
\hline$\geq 4$ & 36 & 13 & 21 & 13 & 15 & 13 & \\
\hline \multicolumn{8}{|l|}{ ECOG } \\
\hline 1 and 2 & 21 & 7 & 10 & 6 & 11 & 9 & \multirow{3}{*}{0.222} \\
\hline 3 & 103 & 36 & 67 & 40 & 36 & 31 & \\
\hline 4 & 162 & 56 & 92 & 54 & 70 & 60 & \\
\hline
\end{tabular}


existence of associations between variables. Survival was defined as the time from admission until death. Survival curves were calculated using the Kaplan-Meier estimator and compared using the log-rank test. The level of significance was deemed to be 0.05 and the software used was IBM SPSS version 25. Missing data were dealt with by listwise deletion.

\section{RESULTS}

From the 300 patients, three had hypernatremia (serum sodium > $145 \mathrm{mEq} / \mathrm{L}$ ) and 20 had duplicate records from which the 10 oldest records were deleted. Therefore, the records of 287 patients were analyzed.

Of the 287 patients, 167 (58\%) were men and the median age was 69 years (range: 19 to $99 ; 1^{\text {st }}$ quartile $60,3^{\text {rd }}$ quartile 77). The most frequent primary cancers were in the digestive tract, namely esophageal/gastric and colorectal cancers (Table 1). The most common metastatic sites were lymph nodes and pleura/lungs; many cancers were locally advanced. Most patients had an Eastern Cooperative Oncology Group (ECOG) performance status of four, 162 (56\%).

There were no significant differences between the group of patients tested for sodium and the group of patients not tested in terms of gender, age, primary cancer, number of metastatic sites or ECOG performance status (Table 1).

Sodium was measured in 170 (59\%) patients. The median serum sodium concentration was $135 \mathrm{mEq} / \mathrm{L}$ (109 to 145). In 91 (54\%) patients, it was in the normal range, while $59(35 \%)$ had mild hyponatremia, 13 (8\%) had moderate hyponatremia and seven (4\%) had profound hyponatremia (Fig. 1). There were no significant differences between the group of patients with and without hyponatremia (Table 2).

Overall, median survival was 13 days (1 to 1020). The median survival of patients who were not tested for serum sodium levels was 10 days (95\% Cl: 6.21 - 13.79) and the median survival of patients who were tested was 14 days (95\% Cl: 9.12 - 18.89), with the difference not being statistically significant ( $p=0.131)$ (Fig. 2). The level of serum sodium did not significantly influence survival $(p=0.463)$. Gender $(p=0.372)$, age $(p=0.928)$, primary cancer $(p=$ $0.059)$ and number of metastatic sites $(p=0.185)$ were not associated with survival and, of the variables analyzed, only the ECOG performance status had a significant association with survival: patients with ECOG 1 and 2 had a median survival of 54 days, patients with ECOG 3 had a median survival of 23 days and patients with ECOG 4 had a median survival of nine days $(p<0.001)$ (Fig. 3).

\section{DISCUSSION}

Hyponatremia is the most frequent body fluid and electrolyte imbalance encountered in clinical practice. ${ }^{1}$ In the few studies carried out in palliative care, the prevalence of hyponatremia has been reported differently: $28.8 \%,^{13}$ $38.7 \%{ }^{14}$ and $63.7 \% .^{9}$ The latter $^{9}$ was also carried out solely on cancer patients, as was the present study. In the study by Kremeike et al, $92.7 \%$ of the patients had cancer ${ }^{14}$ and in the study by Nair et al, $61.1 \%$ had oncological diseases. ${ }^{13}$ In the present study, the prevalence of hyponatremia was $49 \%$. However, the real prevalence of hyponatremia in palliative care remains unknown because, for ethical reasons, a blood test was not obtained from all patients, but only from those who needed a blood test for reasons other than the prevalence study.

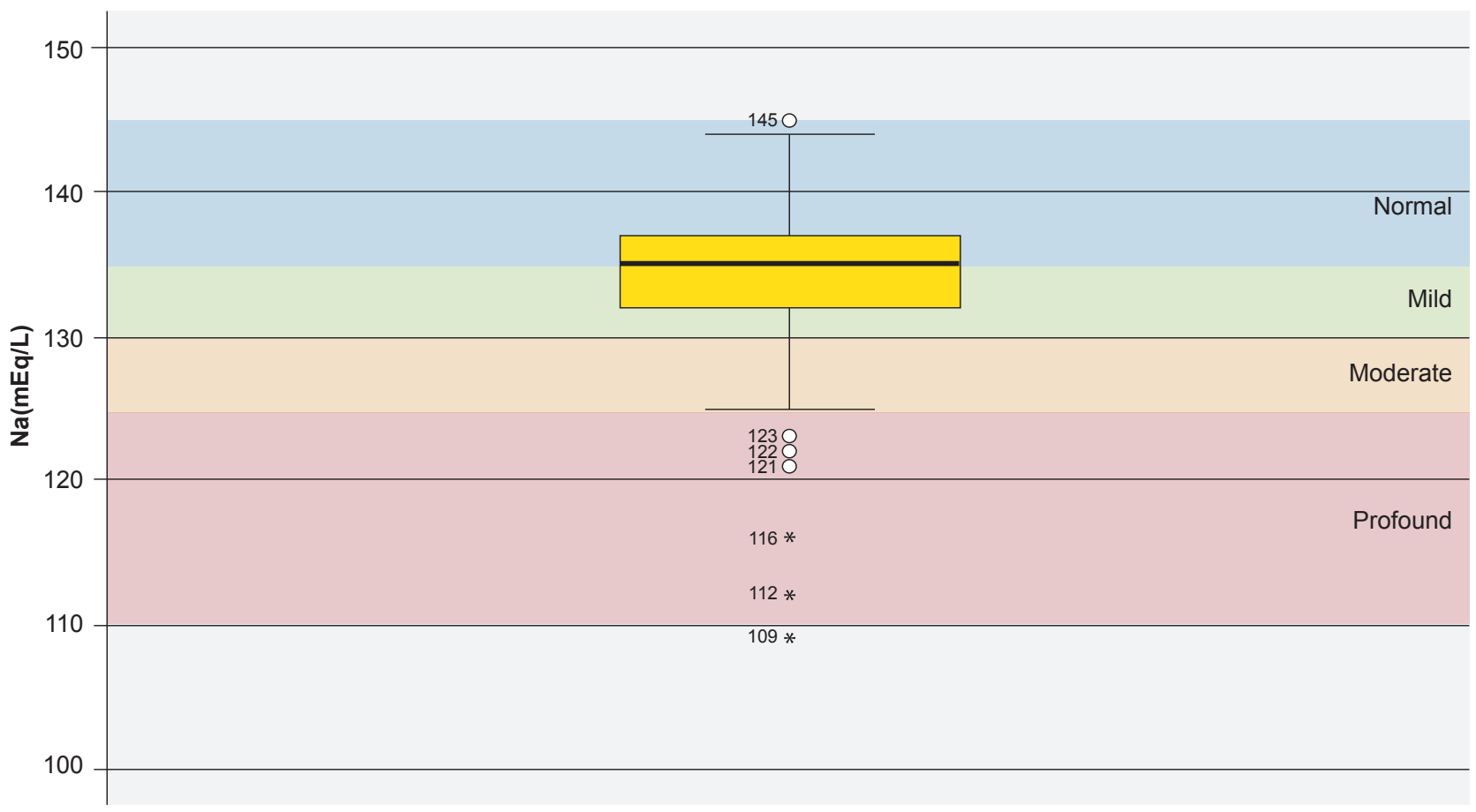

Figure 1 - Distribution of serum sodium levels 
Table 2 - Comparison of patients with normal and low sodium

\begin{tabular}{|c|c|c|c|c|c|c|c|}
\hline \multirow[b]{2}{*}{ Gender } & \multicolumn{2}{|c|}{ Total } & \multicolumn{2}{|c|}{ Normal Na } & \multicolumn{2}{|c|}{ Low $\mathrm{Na}$} & \multirow[b]{2}{*}{$p$} \\
\hline & $\mathbf{n}$ & $\%$ & $\mathbf{n}$ & $\%$ & $\mathbf{n}$ & $\%$ & \\
\hline Male & 102 & 60 & 55 & 60 & 47 & 60 & \multirow{2}{*}{0.900} \\
\hline Female & 68 & 40 & 36 & 40 & 32 & 40 & \\
\hline \multicolumn{8}{|l|}{ Age } \\
\hline$\leq 69$ years & 81 & 48 & 39 & 43 & 42 & 53 & \multirow{2}{*}{0.218} \\
\hline$>69$ years & 89 & 52 & 52 & 57 & 37 & 47 & \\
\hline \multicolumn{8}{|l|}{ Primary cancer } \\
\hline Esophageal/ gastric & 33 & 19 & 19 & 21 & 14 & 18 & \multirow{9}{*}{0.555} \\
\hline Colorectal & 28 & 17 & 10 & 11 & 18 & 23 & \\
\hline Lung & 18 & 11 & 11 & 12 & 7 & 9 & \\
\hline Head and neck & 17 & 10 & 8 & 9 & 9 & 11 & \\
\hline Breast & 17 & 10 & 9 & 10 & 8 & 10 & \\
\hline Prostate & 15 & 8 & 10 & 11 & 5 & 6 & \\
\hline Gynecological & 8 & 5 & 5 & 6 & 3 & 4 & \\
\hline Other & 34 & 20 & 19 & 21 & 15 & 19 & \\
\hline Total & 170 & 100 & 91 & 100 & 79 & 100 & \\
\hline \multicolumn{8}{|c|}{ Disease extension/ Number of metastatic sites } \\
\hline 1 & 40 & 24 & 24 & 26 & 16 & 21 & \multirow{4}{*}{0.430} \\
\hline 2 & 62 & 37 & 30 & 33 & 32 & 42 & \\
\hline 3 & 44 & 26 & 23 & 25 & 21 & 28 & \\
\hline$\geq 4$ & 21 & 13 & 14 & 15 & 7 & 9 & \\
\hline \multicolumn{8}{|l|}{ ECOG } \\
\hline 1 and 2 & 10 & 6 & 6 & 7 & 4 & 5 & \multirow{3}{*}{0.333} \\
\hline 3 & 67 & 40 & 31 & 34 & 36 & 46 & \\
\hline 4 & 92 & 54 & 53 & 59 & 39 & 49 & \\
\hline
\end{tabular}

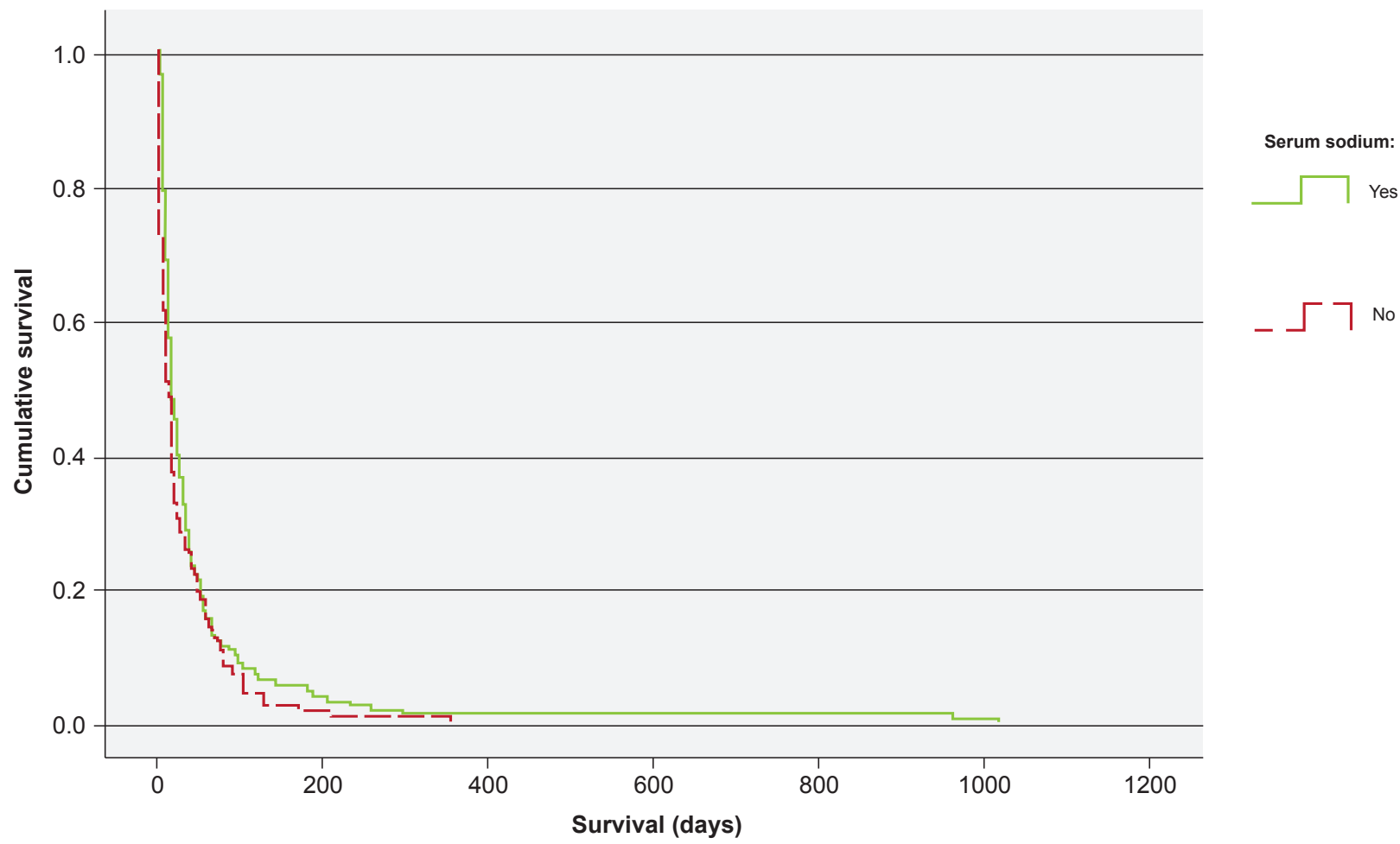

Figure 2 - Survival comparison between patients tested and not tested 
In these studies, like in ours, hyponatremia was defined as a serum sodium below $135 \mathrm{mEq} / \mathrm{L}$, except for one which defined hyponatremia as a serum sodium below 136 $\mathrm{mEq} / \mathrm{L}$. However, different studies in cancer patients have defined hyponatremia diversely from below $130 \mathrm{mEq} / \mathrm{L}$ to below $138 \mathrm{mEq} / \mathrm{L} 2 .^{8}$

A recent study reported an association between hyponatremia and symptom burden. ${ }^{14}$ Nonetheless, symptoms in advanced cancer may result directly from advanced disease and it may be difficult to distinguish what is due to hyponatremia alone and what is the result of other causes. Given these reasons, we did not try to investigate the symptoms that could perhaps result from hyponatremia itself.

There are several studies reporting hyponatremia as an independent factor of a poorer prognosis in patients with cancer. ${ }^{15-20}$ But there are divergences in some of them according to the cancer extension, with one identifying hyponatremia as a prognostic factor in extensive disease ${ }^{19}$ whereas another only in limited disease. ${ }^{18}$ There are also some studies in advanced cancer showing that hyponatremia was independently associated with lower survival, ${ }^{9}$ an increased risk of death among inpatients in palliative care units, ${ }^{12}$ longer hospital stays and higher risk of death ${ }^{10}$ and costs. ${ }^{11}$ However, the association of hyponatremia with a poorer prognosis does not imply causality as it may be a marker of general debility in advanced cancer ${ }^{21}$ or in other diseases. ${ }^{22}$ If this is the case, the correction of hyponatremia would have little impact, if any, on the outcome, but a meta-analysis indicated that the improvement of hyponatremia was associated with a reduction in overall mortality for several diseases. ${ }^{23}$ Nevertheless, this remains debatable and there is a need for randomized controlled trials to evaluate if the correction of hyponatremia improves outcomes. ${ }^{24}$

In this study, we did not find that hyponatremia was associated with a poorer prognosis. The prognosis for inpatients in this group was, in general, poor, as the median survival for patients who had serum sodium levels available was only 14 days. However, another study with similar median survival found an influence of hyponatremia on survival. ${ }^{9}$ We looked at the survival of patients who had not had a blood test (as patients might not have been tested because they could have appeared worse than the others) and we found that, even though median survival was lower, the difference was not statistically significant.

This study has some weaknesses. It was carried out in a single institution, which may limit its generalizability to other settings. Additionally, patients were in a very advanced stage of disease with a consequently short overall life expectancy that may have masked the influence of hyponatremia on the prognosis. Nevertheless, these data suggest that the correction of hyponatremia may not be a priority, as it does not seem to influence survival in this setting.

\section{CONCLUSION}

Around half of the cancer patients hospitalized in the palliative care department had hyponatremia. However, in this end-of-life setting, hyponatremia was not associated with a poorer prognosis.

\section{AUTHORS CONTRIBUTION}

JFG: Conceipt and design of the work and of the protocol, draft of the paper.

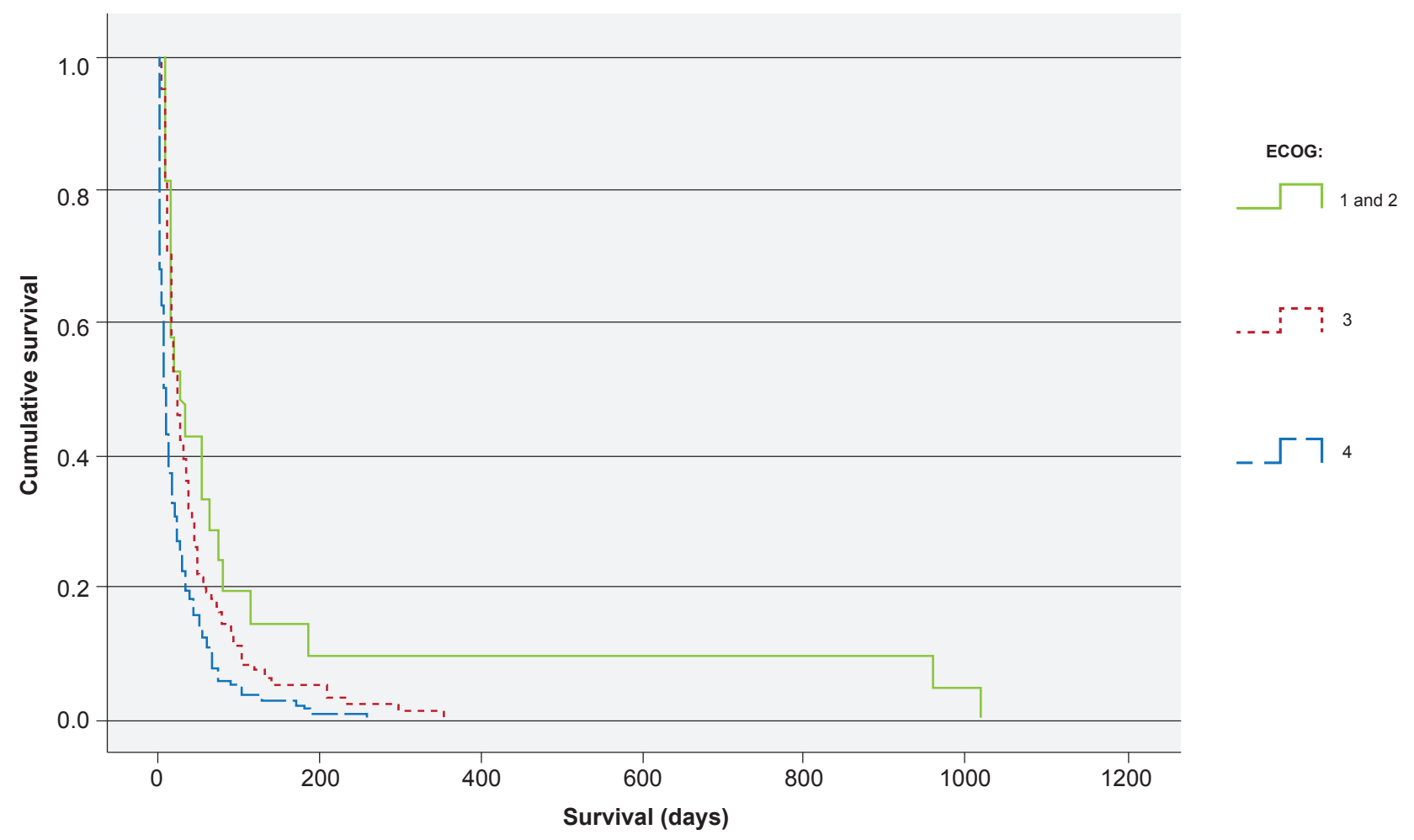

Figure 3 - Survival related with ECOG performance status 
MB: Design of the work and of the protocol, critical review of the paper, final approval of the manuscript.

AA, BP, IG, SF, IC, OM, VA: Criticial review of the proto$\mathrm{col}$ and of the different versions of the paper, data acquisition, final approval of the manuscript.

\section{ACKNOWLEDGEMENT}

This study was supported in part by the North Section of the Portuguese League against Cancer.

\section{PROTECTION OF HUMANS AND ANIMALS}

The authors declare that the procedures were followed according to the regulations established by the Clinical Research and Ethics Committee and to the Helsinki Declara- tion of the World Medical Association, updated in 2013.

\section{DATA CONFIDENTIALITY}

The authors declare having followed the protocols in use at their working center regarding patients' data publication.

\section{COMPETING INTERESTS}

The authors have declared that no competing interests exist.

\section{FUNDING SOURCES}

This study did not receive any funding.

\section{REFERENCES}

1. Spasovski G, Vanholder R, Allolio B, Annane D, Ball S, Bichet D, et al. Clinical practice guideline on diagnosis and treatment of hyponatraemia. Intensive Care Med. 2014:40:320-31.

2. Hoorn EJ, Zietse R. Diagnosis and treatment of hyponatremia: compilation of the guidelines. J Am Soc Nephrol. 2017;28:1340-9.

3. Verzicco I, Regolisti G, Quaini F, Bocchi P, Brusasco I, Ferrari M, et al. Electrolyte disorders induced by antineoplastic drugs. Front Oncol. 2020;10:779

4. Farmand S, Lindh J, Calissendorff J, Skov J, Falhammar H, Nathanson D, et al. Differences in associations of antidepressants and hospitalization due to hyponatremia. Am J Med. 2018;131:56-63.

5. Liamis $\mathrm{G}$, Milionis $\mathrm{H}$, Elisaf $\mathrm{M}$. A review of drug-induced hyponatremia. Am J Kidney Dis. 2008;52:144-53.

6. Moritz ML, Ayus JC. Hospital-acquired hyponatremia - why are hypotonic parenteral fluids still being used? Nat Clin Pract Nephrol. 2007:3:374-82.

7. Fortgens P, Pillay TS. Pseudohyponatremia revisited: a modern-day pitfall. Arch Pathol Lab Med. 2011;135:516-9.

8. Castillo JJ, Vincent M, Justice E. Diagnosis and management of hyponatremia in cancer patients. Oncologist. 2012;17:756-65.

9. Yoon J, Ahn SH, Lee YJ, Kim CM. Hyponatremia as an independent prognostic factor in patients with terminal cancer. Support Care Cancer. 2015;23:1735-40.

10. Doshi SM, Shah P, Lei X, Lahoti A, Salahudeen AK. Hyponatremia in hospitalized cancer patients and its impact on clinical outcomes. Am J Kidney Dis. 2012;59:222-8.

11. Berardi R, Caramanti M, Castagnani M, Guglielmi S, Marcucci F, Savini A, et al. Hyponatremia is a predictor of hospital length and cost of stay and outcome in cancer patients. Support Care Cancer. 2015;23:3095101.

12. Elsayem A, Mori M, Parsons HA, Munsell MF, Hui D, Delgado-Guay MO, et al. Predictors of inpatient mortality in an acute palliative care unit at a comprehensive cancer center. Support Care Cancer. 2010;18:67-76.

13. Nair S, Mary TR, Tarey SD, Daniel SP, Austine J. Prevalence of hyponatremia in palliative care patients. Indian $\mathrm{J}$ Palliat Care. 2016;22:33-7.

14. Kremeike K, Wetter RM, Burst V, Voltz R, Kuhr K, Simon ST. Prevalence of hyponatremia in inpatients with incurable and life-limiting diseases and its association with physical symptoms - a retrospective descriptive study. Support Care Cancer. 2018;26:213-22.

15. Fucà G, Mariani L, Vullo SL, Galli G, Berardi R, Di Nicola M, et al. Weighing the prognostic role of hyponatremia in hospitalized patients with metastatic solid tumors: the HYPNOSIS study. Sci Rep. 2019;9:12993.

16. Castillo JJ, Glezerman IG, Boklage SH, Chiodo J, Tidwell BA, Lamerato LE, et al. The occurrence of hyponatremia and its importance as a prognostic factor in a cross-section of cancer patients. BMC Cancer. 2016;16:564

17. Jacot W, Colinet B, Bertrand D, Lacombe S, Bozonnat MC, Daures JP, et al. Quality of life and comorbidity score as prognostic determinants in non-small-cell lung cancer patients. Ann Oncol. 2008;9:1458-64.

18. Østerlind K, Andersen PK. Prognostic factors in small cell lung cancer: multivariate model based on 778 patients treated with chemotherapy with or without irradiation. Cancer Res. 1986;46:4189-94.

19. Kawahara M, Fukuoka M, Saijo N, Nishiwaki Y, Ikegami H, Tamura T, et al. Prognostic factors and prognostic staging system for small cell lung cancer. Jpn J Clin Oncol. 1997;27:158-65.

20. Jeppesen AN, Jensen HK, Donskov F, Marcussen N, von der Maase H. Hyponatremia as a prognostic and predictive factor in metastatic renal cell carcinoma. Brit J Cancer. 2010;102:867-72.

21. Berghmans $T$, Paesmans $M$, Body J. A prospective study on hyponatraemia in medical cancer patients: epidemiology, aetiology and differential diagnosis. Support Care Cancer. 2000;8:192-7.

22. Chawla A, Sterns RH, Nigwekar SU, Cappuccio JD. Mortality and serum sodium: do patients die from or with hyponatremia. Clin J Am Soc Nephrol. 2011;6:960-5.

23. Corona G, Giuliani C, Verbalis JG, Forti G, Maggi M, PeriA. Hyponatremia improvement is associated with a reduced risk of mortality: evidence from a meta-analysis. PLoS One. 2015;10:e0124105.

24. Peri A. Prognostic and predictive role of hyponatremia in cancer patients. J Cancer Metastasis Treat. 2019;5:40. 